\title{
Eksplorasi dan identifikasi Jamur Patogen Serangga di Rhizosfer Lahan Kering Kabupaten Malang
}

\author{
Exploration and identification of Insect Pathogenic Fungi in Rhizosphere on Dry \\ Land Malang Regency
}

\section{Made Indra Agastya*, Presti Ameliawati, dan Wahyu Fikrinda}

Universitas Tribhuwana Tunggadewi

Email : indra.agastya@unitri.ac.id

\begin{abstract}
This research was conducted by exploring insect pathogen in rhizosphere of dry field of sugar cane of Malang Regency. The purpose of this research is to study the diversity of isolate insect pathogen in rhizosphere of sugar cane plant in dry land of Malang Regency. Exploration activities of insect pathogens are carried out by isolating insect pathogens in dry land of sugarcane plant rhizosphere. Rizosphere soil sampling method using composite sampling technique is by taking diagonal soil samples at five points as deep as $5-10 \mathrm{~cm}$, as much as 200 $g$ at each sample point and isolation of insect pathogen type fungus using baiting method. The soil samples from the field were placed evenly over the petri dish. The soil above the petri dish is moistened and then the larvae of T miltor are placed for incubation for 48 hours. After 48 hours of dead larvae there will be a sign of an insect pathogenic fungus in the form of white hyphae on the surface of the T milter body. The marked larvae were then cultured on PDA media to be purified and identified morphologically, by looking at the color of hyphae. Observation miscroscopically using Burnet and Hunter determinations. Exploration and identification results found four specimens of fungi with Aspergilus sp species, Trichoderma sp, Beuveria sp, and Metharizium sp.
\end{abstract}

Keywords: Biological pesticides, Trichoderma sp, Metharizium sp, Biological control

Disubmit: 21 Desember 2017, Diterima: 5 Januari 2018, Disetujui: 28 Januari 2018

\section{PENDAHULUAN}

Lahan Kering merupakan lahan yang sepanjang tahun tidak tergenang air serta kelembaban tanah sepanjang tahun berada di bawah kapasitas lapang.. Menurut dinas pertanian dan perkebunan Kabupaten Malang (2015) luas lahan di Kab. Malang 49.345 ha merupakan lahan sawah dan lahan bukan sawah mencapai 190.789 ha. Lahan kering di Kabupaten Malang berupa ladang dan kebun/tegalan. Sebagian besar lahan kering digunakan sebagai lahan budidaya tanaman tebu.

Target pencapaian swasembada gula sebesar 5,7 juta ton tentunya membutuhkan kerja nyata. Hasil Produksi tanaman tebu pada lahan kering kabupaten malang pada tahun 2015 mencapai \pm 2.740 .558 ton per musim, ketebatasan hasil produksi tanaman salah satunya disebabkan oleh serangan hama dan penyakit tanaman (Susilowati \& Tinaprilla, 2012). Serangan Scirpophaga nivella pada tanaman tebu berumur 6-7 bulan dapat menurunkan tinggi batang 1 meter dan mengurangi rendemen sejumlah $50 \%$ (Arifin, 2011) Pengendalian hama pada tanaman tebu menggunakan insektisida, yang mengakibatkan resurgensi pada hama sekunder, resistensi hama sasaran, dan musnahnya musuh alami. 
Penggunaan agen biologi merupakan salah satu cara pencegahan rusaknya agroekosistem. Jenis patogen serangga terdapat diberbagai habitat terutama di rizosfer (Alvarez et al., 2004). Rizosfer adalah tanah yang menyelimuti permukaan akar tanaman yang masih dipengaruhi oleh aktivitas akar. Rizosfer merupakan habitat yang sangat baik bagi pertumbuhan patogen serangga, karena akar tanaman dapat menyediakan berbagai bahan organik yang umumnya menstimulir pertumbuhan mikroorganisme (Prasetyawati, 2009).

Rizosfer merupakan salah satu habitat dari patogen serangga. Serangga hama Ordo Lepidoptera membentuk fase prapupa dan pupa pada rizosfer tanaman. Penelitian mengenai isolasi jamur patogen serangga telah dilakukan sebelumnya oleh (Prayogo, 2006) pada rizosfer kedelai dilahan kering Lampung. (Agastya $e t$ al., 2017) juga melaporkan bahwa bakteri patogen serangga B. cereus and B. megaterium yang diisolasi dari rizosfer kedelai lahan kering Kabupaten Lombok Tengah juga dapat menyebabkan kematian larva Spodoptera litura hingga 94,66\%. Isolat patogen serangga dari habitat asal memiliki virulensi yang tinggi sebagai pengendali hama, hal tersebut sesuai dengan pendapat Fargues and Remaudiere (1977) bahwa, strain patogen serangga yang diisolasi dari serangga inang dan lingkungan memiliki virulensi yang tinggi dari strain lain dengan spesies yang sama. Tujuan dari penelitian ini adalah untuk untuk mengkaji keragaman isolat patogen serangga pada rizosfer tanaman tebu di lahan kering Kabupaten Malang.

\section{METODE PENELITIAN}

Penelitian dilaksanakan dengan mengambil sampel tanah pada lapisan rizosfer tanaman tebu. Lokasi pengambilan sampel tanah dilakukan di lahan kering lapisan rizosfer tanaman tebu di Desa Wonokerso, Kecamatan Pakisaji Kabupaten Malang, pada bulan Mei 2017, pengambilan sampel dilakukan pada 5 titik pada lapisan rhizosphere selanjutnya di kompositkan selanjutnya sampel tanah di ambil seberat $200 \mathrm{~g}$, kemudian di bawa menuju laboratorium Hama dan Penyakit Tumbuhan Universitas Brawijaya untuk dilakukan Identifikasi.

Bahan penelitian meliputi sampel tanah yang diperoleh dari lapisan rizosfer tanaman tebu pada lahan kering Wonokerso, Kecamatan Pakis Aji Kabupaten Malang, PDA sebagai medium tumbuh jamur, Tenobrio miltor sebagai media baiting jamur. Alat-alat yang digunakan dalam penelitian adalah Laminar Air Flow Cabinet, cawan petri, Erlenmeyer, mikroskop, Autoclave, Specrofotometer, lampu bunsen, Jarum preparat, alat tulis menulis.

Cara pengambilan sampel tanah lapisan rizosfer menggunakan teknik komposit sampling (Swe et al., 2009), dengan mengambil sampel tanah secara diagonal di lima titik sedalam 5-10 cm, sebanyak 200 g pada tiap titik sampel. Tanah kemudian dikompositkan dan dimasukkan ke dalam kantong plastik lalu dibawa ke Laboratorium Hama dan Penyakit Tumbuhan Universitas Berawijaya. Isolasi Jamur patogen serangga dilakukan dengan menggunakan teknik baiting. Sampel tanah yang berasal dari lapangan di letakkan secara merata di atas cawan petri. Tanah yang berada di atas cawan petri dilembabkan kemudian larva dari T.miltor diletakkan untuk diinkubasikan selama 48 jam. Setelah 48 jam larva yang mati akan terdapat tanda dari jamur patogen serangga berupa hifa berwarna putih di atas permukaan tubuh T. miltor. Larva yang bertanda kemudian dibiakkan pada media PDA untuk dilakukan pemurnian.

Pengamatan dilakukan dengan melihat penampakan secara morfologi dan secara mikroskopis. Penampakan patogen serangga jenis jamur diamati secara pertumbuhan morfologi. Pengamatan secara morfologi dilakukan dengan melihat warna hifa dan pengamatan secara miskroskopis dengan menggunakan determinasi Burnet and Hunter.

\section{HASIL DAN PEMBAHASAN}

Hasil isolasi dan karakterisasi patogen serangga yang terdapat pada lahan kering rizosfer tanaman diperoleh empat isolat jamur. Jamur yang menginfeksi serangga disebut Jamur Entopatogenik. Saat ini telah dikenal lebih dari 750 spesies jamur entopatogenik dan sekitar 100 genera jamur. Berbeda dengan virus, jamur patogen masuk ke dalam tubuh serangga tidak melalui saluran makanan tetapi langsung masuk ke dalam tubuh 
melalui kulit atau integumen. Setelah konodia jamur masuk kedalam tubuh serangga, jamur memperbanyak diri melalui pembentukan hife dalam jaringan epicutikula, epidermis, hemocoel serta jaringan-jaringan lainnya, dan pada akhirnya semua jaringan dipenuhi oleh miselia jamur. Secara morfologi detemukan bahwa jamur yang berpotensi sebagai agen pengendali biologis serangga terdapat pada Tabel 1 .

Tabel 1. Isolasi dan karakterisasi morfologi koloni jamur patogen serangga dari rizosfer tanaman tebu

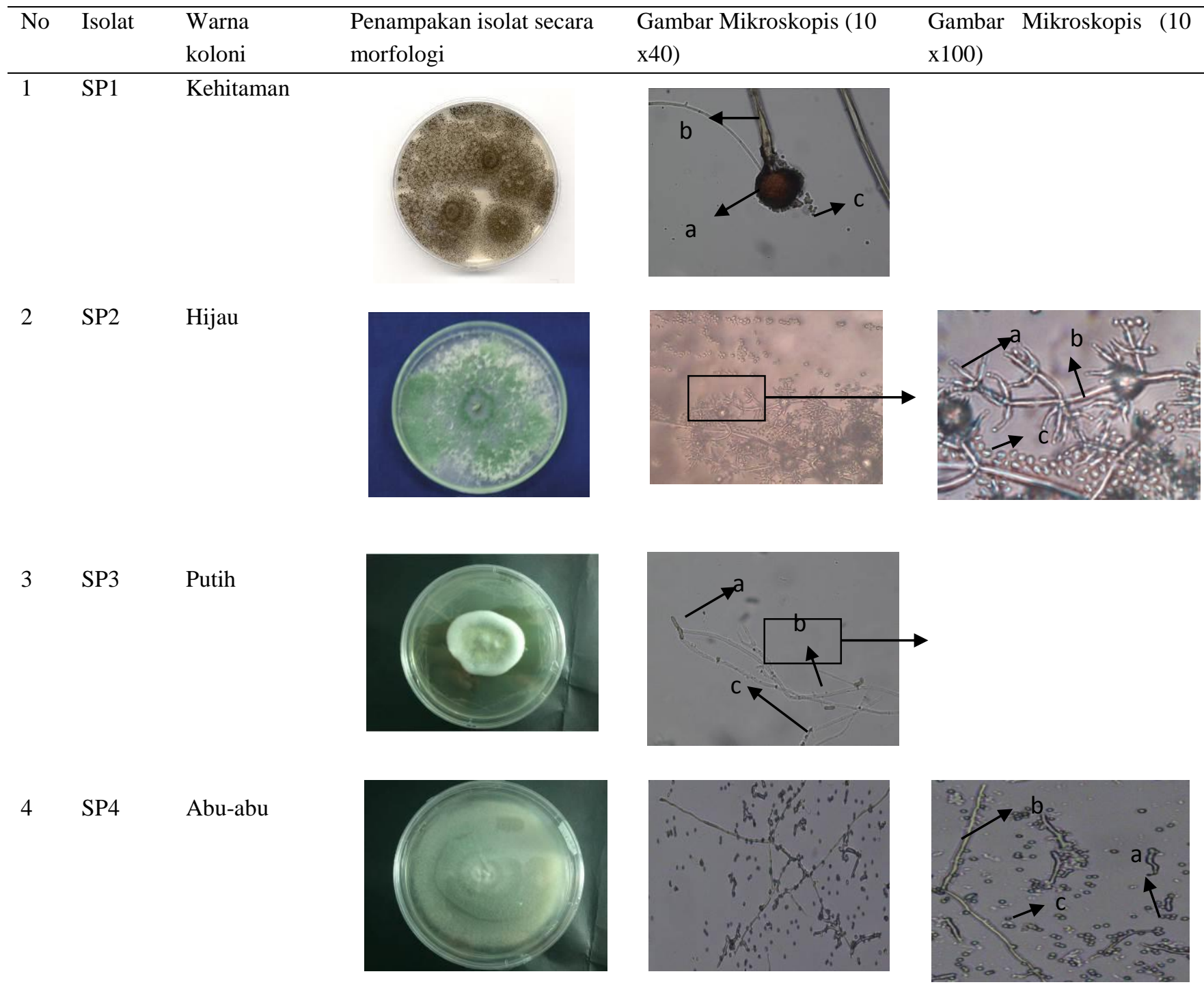

Keterangan: Spesimen diperoleh dengan menggunakan metode baiting (a). Konidia, (b). Hifa, (c). Spora

Isolat jamur patogen serangga yang didapatkan dengan menggunakan metode baiting terdiri atas 4 spesimen. Setelah dilakukan pengamatan secara mikroskopis pada seluruh isolat patogen serangga dengan menggunakan kunci determinasi Burnet and hunter, spesimen jamur pada SP1 merupakan jamur Aspergilus sp, SP2 merupakan jamur Trichoderma sp, SP3 merupakan jamur Beuveria sp, dan SP 4 Merupakan Jamur Metharizium sp

Aspergillus sp. termasuk dalam kelas Ascomycetes yang mudah ditemukan di alam, bersifat saprofit. Aspergillus berkembang biak dengan membentuk hifa dan konodiofora yang membentuk spora. Koloni berwarna putih kekuningan hingga kehitaman. Koloni berbentuk rantai bulat. Reproduksi jamur ini dapat secara seksual dan aseksual (Yosmed, 2010). Jamur Aspergillus terdiri dari beberapa jenis diantaranya adalah Aspergillus niger, Aspergillus flavus, Aspergillus terreus dan Aspergillus parasitivus. Beberapa 
penelitian menunjukkan bahwa jamur Aspergillus niger, Aspergillus flavus dan Aspergillus parasitivus dapat digunakan sebagai biopestisida karena memiliki kemampuan dalam menghasilkan mitokosin untuk membunuh serangga (Meitry \& Rudias, 2015). Trichoderma sp. banyak ditemukan di tanah hutan/pertanian maupun substrat berkayu. Trichoderma sp adalah termasuk dalam kelompok jamur ascomycetes yang memiliki sifat antifungal. Sifat antagonis terhadap jamur lainnya ini kemudian dikembangkan untuk biokontrol pertumbuhan jamur yang bersifat patogen. Aktivitas antagonis tersebut meliputi persaingan parasitisme, predasi, maupun pembentukan toksin (Purnama et al., 2015). Oleh karena itu isolat Trichoderma sp. dimanfaatkan biofungisida alami.

Beauveria bassiana adalah salah satu jamur patogen serangga yang memiliki potensi untuk dikembangkan sebagai agens pengendali hayati. B. bassiana sangat efektif dalam menekan perkembangan larva Lepidoptera (Herlinda et al., 2006). Metharizium. anisopliae hidup secara saprofit dan memiliki ciri Konidiofor tumbuh tegak, spora berbentuk silinder atau lonjong dengan panjang 6-16 mm, warna hialin, bersel satu, $M$. anisopliae mempunyai miselia yang bersepta, dengan konidia yang berbentuk lonjong, massa spora berwarna hijau zaitun. M. anisopliae tumbuh pada $\mathrm{pH}$ 3,3-8,5. M. anisopliae telah banyak digunakan untuk mengendalikan berbagai jenis hama tanaman, antara lain hama tebu (Cleanus punctiventris), kumbang tanduk (Oryctes rhinocheros), hama bubuk kopi, termasuk juga hama penghisap buah kakao (Helopeltis spp) (Witjaksono et al., 2017).

\section{KESIMPULAN}

Berdasarkan hasil penelitian dapat disimpulkan bahwa beberapa jenis isolat patogen serangga berpotensi sebagai pengendali hayati ditemukan di rizosfer lahan kering tanaman tebu. Terdapat empat jenis isolat jamur yang ditemukan yaitu Aspergilus sp, Trichoderma sp, Metharizium sp, dan Beuveria sp.

\section{UCAPAN TERIMA KASIH}

Kami sampaikan terimakasih kepada Direktorat Riset dan Pengabdian kepada Masyarakat (DRPM) Kementerian Riset, Teknologi dan Pendidikan Tinggi yang membiayai kegiatan ini pada skema Penelitian dosen Pemula, tahun 2017. Lembaga Penelitian dan Pengabdian Masyarakat (LPPM) Universitas Tribhuwana Tunggadewi yang telah memfasilitasi kegiatan ini.

\section{DAFTAR PUSTAKA}

Agastya, I.M.I., Afandhi, A. \& Aini, L.Q. 2017. Efektifitas Pestisida Biologis Bacillus Cereus dan Bacillus Megaterium . sebagai Pengendali Spodoptera litura Fabr ( Lepidoptera : Noctuidae) The effectiveness of Biological Pesticides Bacillus cereus and Bacillus megaterium . As Controller of Spodoptera. Jurnal Penelitian Pertanian Terapan, 17(2): 145-148.

Alvarez, C.S., Moraga, E.Q., Tovar, E.G. \& Garcia, P.V. 2004. Isolation , geographical diversity and insecticidal activity of Bacillus thuringiensis from soils in Spain. Microbiological Research, 159: 59-71.

Arifin, K. 2011. Penggunaan Musuh Alami Sebagai Komponen Pengendalian Hama Padi berbasis Ekologi. Pengembangan Inovasi Pertanian, 4(1): 29-46.

Fargues, J. \& Remaudiere, G. 1977. Consideration On The Specificity of Entomopathogenic Fungi. Mycopathology, 62: 31-37.

Herlinda, S., Utama, M.D., Pujiastuti, Y. \& Suwandi 2006. Kerapatan dan Viabilitas Spora Beauveria bassiana (bals.) Akibat Subkultur dan Pengayaan Media, Serta Virulensinya Terhadap Larva Plutella xylostella (Linn.). 6(2): 70-78.

Meitry, T. \& Rudias 2015. Isolasi dan identifikasi cendawan berguna asal poso potensinya sebagai agens pengendali serangga hama. AgroPet, 12(2002): 23-30. 
Prasetyawati, E.T. 2009. Bakteri rhizosfer sebagai pereduksi merkuri dan agensia hayati. UPN Press.

Prayogo, Y. 2006. Sebaran dan Efikasi Berbagai Genus Cendawan Entomopatogen Terhadap Riptortus linearis Pada Kedelai. J. HPT Tropika, 6(1): 14-22.

Purnama, H., Hidayati, N. \& Setyowati, E. 2015. Pengembangan Produksi Pestisida Alami dari Beauveria bassiana dan Trichoderma sp Menuju Pertanian Organik. Warta, 18(1): 1-9.

Susilowati, S.H. \& Tinaprilla, N. 2012. Analisis Efisiensi Usaha Tani Tebu Di Jawa Timur Analysis of Sugar Cane Farming Efficiency in East Java. Jurnal Littri, 18(4): 162-172.

Swe, A., Jeewon, Æ.R., Pointing, Æ.S.B. \& Hyde, Æ.K.D. 2009. from decaying litter in terrestrial , freshwater and mangrove habitats. Biodivers Conserv, 18: 1695-1714.

Witjaksono, Wijonarko, A., Harjaka, T., Harahap, I. \& Sampurno, W.B. 2017. Tekanan Metarhizium anisopliae dan feromon terhdap populasi dan tingkat kerusakan oleh Oryctes rhinoceros. J.Perlindungan Tan.Indonesia, 19(2): 73.

Yosmed, H. 2010. Isolasi Cendawan Entomopatogen Pada Serangga Terinfeksi Di Daerah Pertanian Kecamatan X Koto Tanah Datar. Jurnal Saintek, II(2): 99-104. 